\title{
Symptoms and biomarkers associated with undiagnosed celiac seropositivity
}

Line Lund Kårhus ${ }^{1 *}$, Janne Petersen ${ }^{1,2}$, Katja Biering Leth-Møller ${ }^{1}$, Line Tang Møllehave ${ }^{1}$, Anja Lykke Madsen³ Betina Heinsbæk Thuesen ${ }^{1}$, Peter Schwarz ${ }^{4,5}$, Jüri J. Rumessen ${ }^{6}$ and Allan Linneberg ${ }^{1,5}$

\begin{abstract}
Background: Studies have indicated that underdiagnosis and diagnostic delay are common in celiac disease. Therefore, it is important to increase our knowledge of what symptoms and biomarkers could identify undiagnosed cases of celiac disease.

Methods: We screened for celiac disease antibodies in stored blood samples from 16,776 participants in eight population-based studies examined during 1976-2012. Undiagnosed celiac seropositivity was defined as celiac disease antibody positivity (IgG-deamidated gliadin peptide above $10.0 \mathrm{U} / \mathrm{mL}$ and/or IgA-tissue transglutaminase (TTG) or IgG-TTG above $7.0 \mathrm{U} / \mathrm{mL}$ ) without a known diagnosis of celiac disease in the National Patient Register. In all studies general health symptoms were recorded by participant-completed questionnaire, including self-perceived health, tiredness, headache and gastrointestinal symptoms. Furthermore, blood samples were drawn for analyses of biomarkers e.g. hemoglobin, blood glucose, cholesterol, liver parameters and vitamins. The participants with undiagnosed celiac seropositivity were matched by sex, age and study with four controls among the celiac disease antibody negative participants.
\end{abstract}

Results: We excluded, five participants with known celiac disease, resulting in a population of 16,771 participants. In this population $1 \%(169 / 16,771)$ had undiagnosed celiac seropositivity. There were no statistically significant differences in symptoms between cases and controls. Undiagnosed celiac seropositivity was associated with low blood cholesterol ( $<5 \mathrm{mmol} / \mathrm{L}$ ) and low hemoglobin $(<7.3 \mathrm{mmol} / \mathrm{L}$ for women and $<8.3 \mathrm{mmol} / \mathrm{L}$ for men).

Conclusion: In this general population study, undiagnosed cases of celiac seropositivity did not have more symptoms than controls, confirming the diagnostic difficulties of celiac disease and the low prognostic value of symptoms for a diagnosis of celiac disease. Furthermore, decreased levels of cholesterol and/or hemoglobin in the blood were associated with undiagnosed celiac seropositivity.

Keywords: Antibodies, Celiac disease, Epidemiology, Screening, Symptoms, Biomarkers

\section{Background}

Celiac disease $(C D)$ is a lifelong autoimmune disease caused by an abnormal immune response triggered by the ingestion of gluten-containing grains (wheat, rye

\footnotetext{
*Correspondence: line.lund.kaarhus@regionh.dk

${ }^{1}$ Center for Clinical Research and Prevention, Bispebjerg

and Frederiksberg Hospital, Hovedvejen, Entrance 5, Nordre Fasanvej 57,

2000 Frederiksberg, Copenhagen, Denmark

Full list of author information is available at the end of the article
}

and barley) in genetically susceptible individuals [1]. $\mathrm{CD}$ is a systemic disease occurring at every age affecting around $1 \%$ of the population [2]. However, many cases of CD remain undiagnosed [1,3-8]. CD primarily affects the small intestine, but the clinical manifestations are broad. The treatment of $C D$ is life-long gluten-free diet. A small intestinal biopsy, and detection of villus atrophy and inflammation, has been gold standard for the diagnosis of CD. However, detection of CD specific antibodies, mainly immunoglobulin (Ig) A 
against tissue transglutaminase (TTG), the autoantigen in $\mathrm{CD}$, has become increasingly important in the diagnostic process and screening for $\mathrm{CD}[1,9]$. Screening for $C D$ among individuals without classical symptoms of $\mathrm{CD}$ or in the general population remains a controversial issue, e.g. because many screen-detected cases have few or no symptoms, and little is known about the prognosis of undiagnosed CD. However, screening might be important as a Swedish study found the mean delay to diagnosis was 10 years from the first symptoms and 6 years from the first doctor visit [10]. Additionally, there is evidence to suggest that asymptomatic patients with serological biomarkers for CD may also benefit from a gluten-free diet [11].

In Denmark, the prevalence of diagnosed CD is lower than in other European countries, despite recent increases in prevalence of $C D$ recorded in national registries $[12,13]$. Furthermore, we have previously shown that $C D$ is markedly underdiagnosed in the general population: the screening-prevalence was ten times the registered prevalence [14]. Additionally, we found no differences in symptoms before screening among participants with and without screen-detected CD [15], in line with other studies $[16,17]$. This illustrates the difficulty of identifying CD by symptoms. In the present study we used the population earlier described in Kårhus et al. [18] with data from eight populationbased cohort studies comprising 16,776 participants examined during 1976-2012. We aimed to investigate whether participants with undiagnosed $C D$, as defined by $C D$ antibody positivity without a known diagnosis of $\mathrm{CD}$, had more symptoms or affected biomarkers compared with $\mathrm{CD}$ antibody negative participants.

\section{Methods}

As described earlier [18], we used data from eight population-based studies carried out during 1976-2012 at the Center for Clinical Research and Prevention; The 5-year follow-up of The Health 2006 study [14, 15], The Inter99 study [19, 20], The 1936-cohort study [21], The MonicaI study [22], The Monica-II study [23], The Monica-III study [22, 23], The 1914-cohort study [24, 25], and The Allergy 90 study [26, 27]. In all studies a random sample, or an age-stratified random sample, was drawn from persons living in the Western part of Copenhagen, Denmark. Participants were invited to a health examination including self-administered questionnaires and blood sampling. Figure 1 gives an overview of the studies included and formation and flow of the study-population. More information about the studies is included in Additional file 1: Additional Material. The screening for $\mathrm{CD}$ has been described elsewhere [18]. Briefly, 16,776 participants with available serum were screened for $\mathrm{CD}$ antibodies by the EliA ${ }^{\mathrm{TM}}$ Celikey $^{\circledR}{ }^{\mathrm{T}}$ TTG anti-IgA and anti-IgG assay, and DGP anti-IgG assays, and 169 participants were identified with undiagnosed celiac seropositivity (Table 1).The measurements were performed at Thermo Fisher Scientific, ImmunoDiagnostics, Allerød, Denmark.

\section{Register data}

All the identified participants were linked on an individual level to the National Patient Register by use of the unique personal identification number [28]. The National Patient Register holds information on diagnose codes (international classification of disease (ICD)-8 and ICD10) registered from 1977 [29], for this study we used information on registered $\mathrm{CD}$, i.e. diagnosis codes for $\mathrm{CD}$

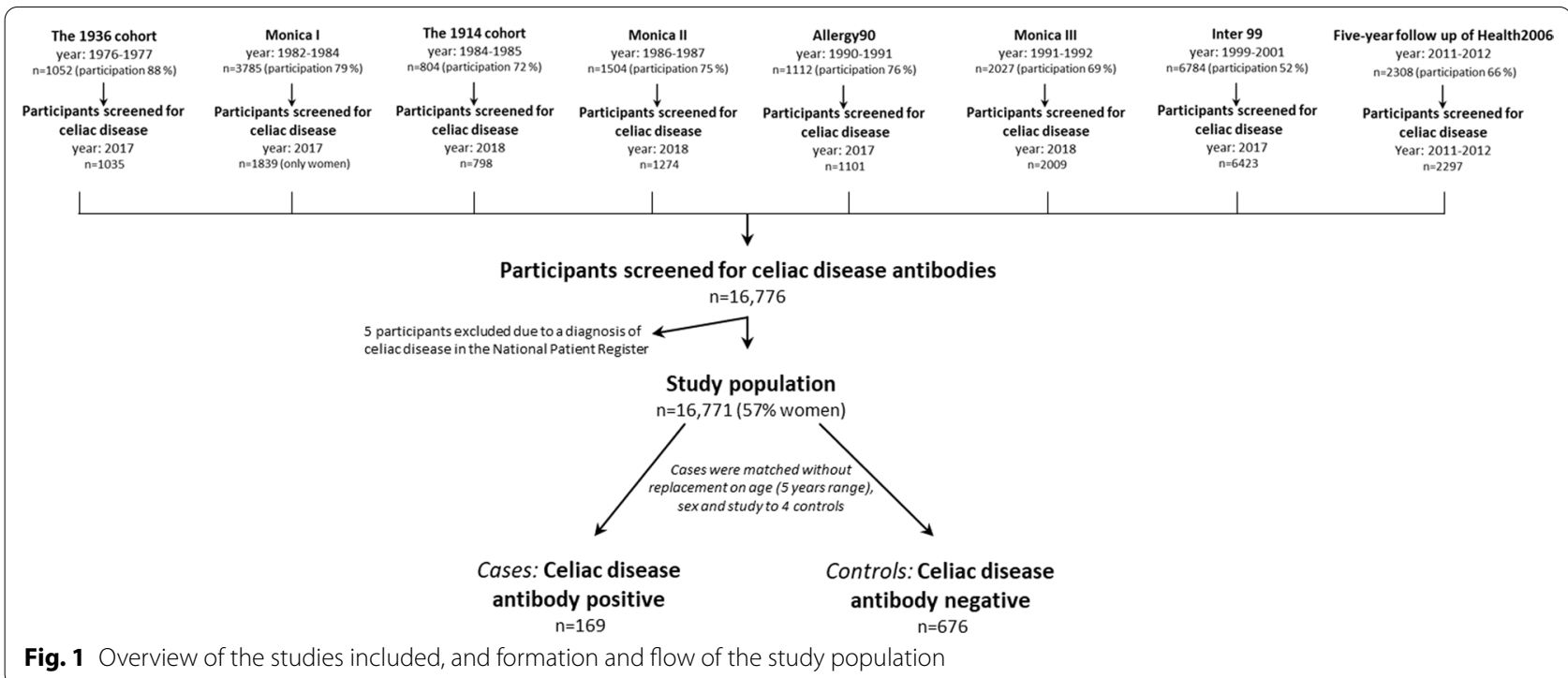


Table 1 General characteristics of the cases and controls

\begin{tabular}{|c|c|c|c|}
\hline & $\begin{array}{l}\text { Cases: Celiac disease antibody positive } \\
\text { participants }^{\mathrm{a}}\end{array}$ & Controls & $p$ value $^{b}$ \\
\hline \multirow[t]{2}{*}{ Number of participants } & 169 & 676 & \\
\hline & $\%(n /$ total N) & $\%(\mathrm{n} /$ total $\mathrm{N})$ & \\
\hline \multicolumn{3}{|l|}{ Sex } & $N A^{c}$ \\
\hline Male & $49.7(84 / 169)$ & $49.7(336 / 676)$ & \\
\hline Female & $50.3(85 / 169)$ & $50.3(340 / 676)$ & \\
\hline \multicolumn{3}{|l|}{ Education (vocational training) } & $0.736^{*}$ \\
\hline Yes & $77.3(126 / 163)$ & $78.5(519 / 661)$ & \\
\hline No & $22.7(37 / 163)$ & $21.5(142 / 163)$ & \\
\hline \multicolumn{3}{|l|}{ Smoking } & $0.143^{*}$ \\
\hline Current smoker & $36.5(61 / 167)$ & $41.8(281 / 673)$ & \\
\hline Past smoker & $24.0(40 / 167)$ & $26.8(180 / 673)$ & \\
\hline \multirow[t]{2}{*}{ Never smoker } & $39.5(66 / 167)$ & $31.5(212 / 673)$ & \\
\hline & Mean $(95 \% \mathrm{Cl})$ & Mean $(95 \% \mathrm{Cl})$ & \\
\hline Age at examination ${ }^{c}$ & $49.0(47.3-50.7)$ & $48.7(47.9-49.6)$ & $0.759^{c \neq}$ \\
\hline \multirow[t]{2}{*}{ Body mass index (BMI) } & $26.2(25.5-26.9)$ & $25.8(25.5-26.2)$ & $0.353^{\ddagger}$ \\
\hline & Median (5\%/95\%) & Median (5\%/95\%) & \\
\hline Alcohol consumption: Units per week & $5.0(0.0 / 33.0)$ & $6.0(0.0 / 31.0)$ & $0.198^{\dagger}$ \\
\hline \multicolumn{4}{|c|}{${ }^{*}$ Chi-Square test; ${ }^{\dagger}$ Wilcoxon Two-sample test; ${ }^{\ddagger}$ Independent samples $t$ test } \\
\hline \multirow{2}{*}{\multicolumn{4}{|c|}{$\begin{array}{l}\text { a The participants were screened for celiac disease antibodies by EliA }{ }^{\mathrm{TM}} \text { Celikey }{ }^{\circledR} \text { tissue transglutaminase (TTG) anti-lgA and anti-lgG assays and deamidated gliadin } \\
\text { peptide (DGP) anti-lgG assays. Celiac disease antibody positive were defined as IgG-DGP } \geq 10.0 \mathrm{U} / \mathrm{mL} \text { and/or IgA-TTG/lgG-TTG } \geq 7.0 \mathrm{U} / \mathrm{mL} \text {. } 5 \text { of the } 16,776 \text { participants } \\
\text { had a diagnosis of celiac disease in the national patient register, they were all celiac disease antibody negative and were excluded before matching } \\
\text { b } p \text { value between antibody negative and antibody positive (case:controls) }\end{array}$}} \\
\hline & & & \\
\hline \multicolumn{4}{|c|}{ c Cases were matched without replacement on age ( 5 years range), sex and study to 4 controls among the antibody negative participans } \\
\hline
\end{tabular}

(ICD-10: K90.0 and ICD-8: 269.00), in order to exclude individuals with a known diagnosis of $\mathrm{CD}$.

\section{Symptoms}

In all studies general health symptoms were recorded by participant-completed questionnaire, including self-perceived health, tiredness, headache and gastrointestinal symptoms. The questionnaires vary through the studies and therefore the wording was not the same in all eight cohorts and some data-harmonization was done, mostly questionnaire answers with more than two answercategories were dichotomized. The numbers of answers for each symptom in the different cohorts are shown in Additional file 1: Table 1.

\section{Biomarkers}

All studies included blood samples and we examined levels of blood lipids, blood glucose, vitamin D and B12, markers of liver function and anemia as these biomarkers have been shown associated with diagnosed CD. Quartiles for each biomarker were calculated per each study and reference levels for the clinical cut-offs were chosen with reference to guidelines [30]. The methods for biomarker determination and the number of available biomarkers varied between the studies. For the chosen biomarkers in this study the Allergy 90 study had no biomarker results, while the other cohorts had one or more measurements. The numbers and presence of biomarkers for each symptom in the different cohorts are shown in Additional file 1: Table 2.

\section{Statistics}

Cases, the antibody positive participants, were matched without replacement by age ( 5 years range), sex and study to four controls, antibody negative participants. The 169 participants with undiagnosed celiac seropositivity were matched with four antibody negative participants, giving 676 controls. We compared the cases and controls on general characteristics (Table 1) and found that the groups were similar also on education, body mass index (BMI), smoking and alcohol consumption in addition to the matching criteria sex and age.

Conditional logistic regression was performed in comparisons of cases and controls, to account for homogeneity among matched participants. General characteristics were compared between cases and controls using; Wilcoxon test and Independent samples $t$ test for continuous variables; and Chi-Square test for categorical data. Complete case analyses were performed thus the number of observations differs due to missing data. Confidence 
intervals (CIs) not including 1.0 and $p$ values $<0.05$ (twosided) were considered as significant. Statistical analyses were performed with software package SAS 9.4 and SAS Enterprise Guide 7.1 (SAS Institute, NC, USA).

\section{Results}

A total of 16,776 individuals was screened for CD antibodies. Among these, five participants had a diagnosis of CD in The National Patient Register and were therefore excluded, resulting in a study population of 16,771 individuals; 9515 women and 7256 men. The five participants with a diagnosis of $\mathrm{CD}$ in the register were all
$\mathrm{CD}$ antibody negative. The prevalence of undiagnosed celiac seropositivity, defined by $\mathrm{CD}$ antibody positivity (IgG-DGP $\geq 10.0 \mathrm{U} / \mathrm{mL}$ and/or IgA-TTG or IgGTTG $\geq 7.0 \mathrm{U} / \mathrm{mL}$ ) without a known diagnosis of $\mathrm{CD}$, was $1 \%(169 / 16,771)$. The 169 participants with undiagnosed celiac seropositivity were matched with four antibody negative participants, giving 676 controls.

Table 2 shows the comparison of symptoms between cases and controls, both for general symptoms and abdominal symptoms; there were no significant differences between the two groups. However, there was a tendency of more tiredness $(29.9 \%$ vs. $26.9 \%)$ and

Table 2 Comparison of self-reported symptoms ${ }^{\mathrm{a}}$ between cases and controls

\begin{tabular}{|c|c|c|c|}
\hline & $\begin{array}{l}\text { Cases: Celiac disease antibody positive } \\
\text { participants }^{\mathbf{b}}\end{array}$ & Controls & OR $(95 \% \mathrm{CI})^{\mathrm{c}}$ \\
\hline \multirow[t]{2}{*}{ Number of participants } & 169 & 676 & \\
\hline & $\%$ (n/total N) & $\%(n /$ total N) & \\
\hline \multicolumn{4}{|l|}{ Tiredness } \\
\hline Yes & $29.9(50 / 167)$ & $26.9(180 / 670)$ & $1.14(0.79-1.66)$ \\
\hline No & $70.1(117 / 167)$ & $73.1(490 / 670)$ & Ref \\
\hline \multicolumn{4}{|l|}{ Self-perceived health } \\
\hline Very good/excellent & $26.2(38 / 145)$ & $30.1(178 / 592)$ & Ref \\
\hline Good & $66.2(96 / 145)$ & $57.6(341 / 592)$ & $1.37(0.90-2.10)$ \\
\hline Fair/poor & $7.6(11 / 145)$ & $12.3(73 / 592)$ & $0.73(0.35-1.52)$ \\
\hline \multicolumn{4}{|l|}{ Headache } \\
\hline Yes & $54.4(81 / 149)$ & $51.1(314 / 615)$ & $1.32(0.80-2.18)$ \\
\hline No & $45.6(68 / 149)$ & $48.9(301 / 615)$ & Ref \\
\hline \multicolumn{4}{|l|}{ Abdominal pain } \\
\hline Yes & $24.9(41 / 165)$ & $27.1(181 / 669)$ & $0.92(0.62-1.37)$ \\
\hline No & $75.2(124 / 165)$ & $72.9(488 / 669)$ & Ref \\
\hline \multicolumn{4}{|l|}{ Bloating } \\
\hline Yes & $65.8(77 / 117)$ & $64.0(301 / 470)$ & $1.12(0.72-1.74)$ \\
\hline No & $34.2(40 / 117)$ & $36.0(169 / 470)$ & Ref \\
\hline \multicolumn{4}{|l|}{ Reflux } \\
\hline Yes & $44.3(31 / 70)$ & $39.0(112 / 287)$ & $1.26(0.73-2.17)$ \\
\hline No & $55.7(39 / 70)$ & $61.0(175 / 287)$ & Ref \\
\hline \multicolumn{4}{|l|}{ Rumbling } \\
\hline Yes & $42.0(66 / 157)$ & $42.3(294 / 622)$ & $0.82(0.57-1.18)$ \\
\hline No & $58.0(91 / 157)$ & $52.7(328 / 622)$ & Ref \\
\hline \multicolumn{4}{|l|}{ Alternating stool } \\
\hline Yes & $68.0(106 / 156)$ & $67.6(421 / 623)$ & $1.02(0.69-1.51)$ \\
\hline No & $32.1(50 / 156)$ & $32.4(202 / 623)$ & Ref \\
\hline \multicolumn{4}{|l|}{ Nausea } \\
\hline Yes & $23.8(10 / 42)$ & $20.4(34 / 167)$ & $1.23(0.54-2.82)$ \\
\hline No & $76.2(32 / 42)$ & $79.6(133 / 167)$ & Ref \\
\hline
\end{tabular}

a The information on self-reported symptoms were collected in questionnaires answered by the participants prior to examination and blood sample collection

${ }^{\mathrm{b}}$ The participants were screened for celiac disease antibodies by EliA ${ }^{\mathrm{TM}}$ Celike ${ }^{\circledR}$ tissue transglutaminase (TTG) anti-lgA and anti-lgG assays and deamidated gliadin peptide (DGP) anti-IgG assays. Celiac disease antibody positive were defined as IgG-DGP $\geq 10.0 \mathrm{U} / \mathrm{mL}$ and/or IgA-TTG/lgG-TTG $\geq 7.0 \mathrm{U} / \mathrm{mL}$. 5 of the 16,776 participants had a diagnosis of celiac disease in the national patient register, they were all celiac disease antibody negative and were excluded before matching. Cases were matched without replacement on age (5 years range), sex and study to 4 controls

${ }^{c}$ Conditional logistic regression for comparison of cases with controls giving odds ratios (ORs) with $95 \%$ confidence intervals (Cls) 
headache $(54.4 \%$ vs. $51.1 \%)$ among the cases. While, for the abdominal symptoms there was no clear tendency, some symptoms such as bloating, reflux and nausea were more frequent among the cases, but the cases had lower frequency of abdominal pain.

We compared levels of biomarkers between cases and controls, in Table 3 the odds ratios (ORs) are shown by quartiles. Only for the 1st quartile of cholesterol we found a significant association, indicating that individuals with low cholesterol are more likely to have undiagnosed celiac seropositivity. This is confirmed in the analyses with a clinical cut-off for cholesterol at $5 \mathrm{mmol} / \mathrm{L}$, where we also found a significant association (OR 1.60, 95\% CI 1.08-2.37). For hemoglobin we found no association when analyzing the quartiles, but when we use the clinical cut-off for anemia $(7.3 \mathrm{mmol} / \mathrm{L}$ for women and $8.3 \mathrm{mmol} / \mathrm{L}$ for men) we found a significant association (OR 3.82, 95\% CI 1.14-12.79), i.e. individuals with anemia are more likely to have undiagnosed celiac seropositivity. When we used the cut-off of $12 \mu \mathrm{g} / \mathrm{L}$ or less, used in an earlier study [9], we found a significant association of iron-deficiency and undiagnosed celiac seropositivity (OR:2.87, 95\% CI 1.28-6.45, $p=0.011$ ). We found no significant association for liver parameters and undiagnosed celiac seropositivity, nor for fasting blood sugar, serum 25-hydroxy Vitamin D or serum Vitamin B12.

\section{Discussion}

In this study the 169 participants (1\%) with undiagnosed celiac seropositivity were matched with four controls among the $\mathrm{CD}$ antibody negative participants. The cases and controls were compared regarding general symptoms, abdominal symptoms and biomarkers. Our results showed no significant differences in symptoms, but for low serum cholesterol measurements $(<5 \mathrm{mmol} / \mathrm{L})$ and low blood hemoglobin $(<7.3 \mathrm{mmol} / \mathrm{L}$ for women and $<8.3 \mathrm{mmol} / \mathrm{L}$ for men) we found a significant association with undiagnosed celiac seropositivity. Thus, this study confirms the diagnostic difficulties of $\mathrm{CD}$ and the low prognostic value of symptoms for a diagnosis of CD.

This study confirm our previous findings [15] of no marked differences in symptoms among individuals with or without $\mathrm{CD}$, also in this large population-based study comprising 16,771 individuals screened for CD antibodies. Hence, we also confirm the low predicative value of symptoms in the diagnostics of $\mathrm{CD}$, found in other studies $[6,16,17]$. Furthermore, in line with others $[31,32]$ we found an association between decreased levels of cholesterol and undiagnosed celiac seropositivity. Also, in our earlier study we found that screening-detected clinical verified cases of $C D$ had significantly lower cholesterol, but we found no significant association for the antibody positive participants in total. In agreement with anemia being a known complication to $\mathrm{CD}$ [1], and findings by West et al. [32], we found that low levels of blood hemoglobin had a significant association with undiagnosed celiac seropositivity, but we found no significant association in the quartiles-analyses. An American population-study [31] found no significant association between blood hemoglobin and undiagnosed CD, but they found a significant association for lower levels of serum ferritin. In the present study we found no significant differences in levels of serum ferritin among the cases and controls although there might be a tendency towards lower serum ferritin among the cases $(74.5$ vs. $78.0 \mu \mathrm{g} / \mathrm{L})$. Also, Murray et al. [33] showed an association of iron-deficiency and CD. However, they used a cut-off for iron-deficiency of $12 \mu \mathrm{g} / \mathrm{L}$ or less. When we use the same cut-off in our study-population we find a significant association of iron-deficiency and undiagnosed celiac seropositivity (OR 2.87, 95\% CI 1.28-6.45, $p=0.011$ ). Indicating that for very low levels of serum ferritin, there might be an association with undiagnosed CD. It is however important to note the possibility of low iron, normal ferritin iron deficiency anemia, as ferritin is affected by other factors and can be in normal range fx. in patients with chronic disease.

In the present study we confirm the low prevalence of diagnosed CD; in this cohort 5 of the 16,776 screened individuals had a known diagnosis of CD in the National Patient Register (0.03\%). This is consistent with a Danish register study showing the prevalence of diagnosed $\mathrm{CD}$ in adults increasing from $0.08 \%$ in 2006 to $0.18 \%$ in 2016 [13]. When we screen for CD antibodies in this population, we illustrate a large proportion of undiagnosed celiac seropositivity $(0.03 \%$ vs. $1 \%)$, in line with our previous results $[14,15]$.

The population-based design is a strength of our study, since it may reflect a relevant non-clinical setting for screening of a wider population. Furthermore, the availability of stored blood samples for $\mathrm{CD}$ antibody measurements and linkage to nation-wide registries to exclude diagnosed cases of $\mathrm{CD}$ offered a unique opportunity to carry out this study. However, selection and response bias might be a limitation. Furthermore, our study might be limited by the slight uncertainty of the diagnosis of $C D$ in the biobank analyses as clinical diagnosis and biopsies were not possible. Nevertheless, we know from our earlier study [15] that the positive predictive values of the chosen CD-antibody positivity were high. However, Hoerter et al. [34] found the positive predictive value of IgG DGP antibodies in TTG negative individuals to be low, this is a potential limitation, as $0.35 \%$ of this study population only were IgG-DGP positive. Additionally, even with such a large cohort there is a power problem as the prevalence of undiagnosed celiac seropositivity is $1 \%$, and 
Table 3 Comparison of levels of biomarkers between cases and controls

\begin{tabular}{|c|c|c|c|c|}
\hline & $\begin{array}{l}\mathrm{N} \text { measurements ( } \mathrm{n} \text { cases/ } \mathrm{n} \\
\text { controls) }\end{array}$ & $\begin{array}{l}\text { Cases: Celiac disease } \\
\text { antibody positive } \\
\text { participants }^{\mathrm{a}}\end{array}$ & Controls & OR $(95 \% \mathrm{Cl})^{\mathrm{b}}$ \\
\hline \multirow[t]{2}{*}{ Number of participants } & & 169 & 676 & \\
\hline & & Median (5\%/95\%) & Median (5\%/95\%) & \\
\hline Cholesterol $(\mathrm{mmol} / \mathrm{L})^{*}$ & 790 (cases:158/controls:632) & $5.5(3.7 / 8.0)$ & $5.7(4.1 / 7.8)$ & \\
\hline 1st quartile & & & & $1.56(0.92-2.62)$ \\
\hline 2nd quartile & & & & $1.02(0.60-1.74)$ \\
\hline 3rd quartile & & & & $0.84(0.50-1.43)$ \\
\hline \multirow[t]{2}{*}{ 4th quartile } & & & & Ref \\
\hline & & $\%(n / N)$ & $\%(\mathrm{n} /$ total $N)$ & \\
\hline \multirow[t]{2}{*}{ Cholesterol under $5 \mathrm{mmol} / \mathrm{L}$} & & $37.3(59 / 158)$ & $28.3(179 / 632)$ & $1.60(1.08-2.37)$ \\
\hline & & Median (5\%/95\%) & Median (5\%/95\%) & \\
\hline Hemoglobin (mmol/L)* & 235 (cases:48/controls:187) & $8.4(7.2 / 9.8)$ & $8.6(7.6 / 9.9)$ & \\
\hline 1st quartile & & & & $1.44(0.47-4.40)$ \\
\hline 2nd quartile & & & & $0.63(0.21-1.83)$ \\
\hline 3rd quartile & & & & $0.63(0.21-1.88)$ \\
\hline \multirow[t]{2}{*}{ 4th quartile } & & & & Ref \\
\hline & & $\%(\mathrm{n} /$ total $N)$ & $\%(n / N)$ & \\
\hline \multirow[t]{2}{*}{ Low hemoglobinc } & & $12.5(6 / 48)$ & $4.3(8 / 187)$ & $3.82(1.14-12.79)$ \\
\hline & & Median (5\%/95\%) & Median (5\%/95\%) & \\
\hline Fasting blood glucose $(\mathrm{mmol} / \mathrm{L})^{*}$ & 549 (cases:110/controls:439) & $4.8(4.0 / 6.0)$ & $4.8(3.9 / 6.3)$ & \\
\hline 1st quartile & & & & $0.84(0.46-1.54)$ \\
\hline 2nd quartile & & & & $1.00(0.56-1.79)$ \\
\hline 3rd quartile & & & & $0.68(0.38-1.23)$ \\
\hline 4th quartile & & & & Ref \\
\hline \multirow[t]{2}{*}{ Fasting blood glucose over $7 \mathrm{mmol} / \mathrm{L}$} & & $1.8(2 / 110)$ & $2.5(11 / 439)$ & $0.69(0.14-3.48)$ \\
\hline & & Median (5\%/95\%) & Median (5\%/95\%) & \\
\hline $\operatorname{HbA1c}(\%)^{*}$ & 474 (cases:95/controls:379) & $5.8(4.9 / 6.5)$ & $5.8(5.0 / 6.5)$ & \\
\hline 1st quartile & & & & $1.26(0.61-2.57)$ \\
\hline 2nd quartile & & & & $1.01(0.53-1.92)$ \\
\hline 3rd quartile & & & & $1.14(0.62-2.08)$ \\
\hline \multirow[t]{2}{*}{ 4th quartile } & & & & Ref \\
\hline & & Median (5\%/95\%) & Median (5\%/95\%) & \\
\hline Ferritin $(\mu \mathrm{g} / \mathrm{L})^{*}$ & 455 (cases:92/controls:363) & $74.5(6.0 / 311.0)$ & $78.0(8.0 / 298.0)$ & \\
\hline 1st quartile & & & & $1.41(0.65-3.05)$ \\
\hline 2nd quartile & & & & $0.72(0.36-1.43)$ \\
\hline 3rd quartile & & & & $0.69(0.35-1.34)$ \\
\hline 4th quartile & & & & Ref \\
\hline ALAT (Alanine transaminase)* $(\mathrm{U} / \mathrm{L})$ & 465 (cases:94/controls:371) & $10.8(6.6 / 33.0)$ & 10.2(6.6/32.0) & \\
\hline 1st quartile & & & & $0.67(0.17-2.73)$ \\
\hline 2nd quartile & & & & $0.63(0.15-2.56)$ \\
\hline 3rd quartile & & & & $1.43(0.41-4.07)$ \\
\hline 4th quartile & & & & Ref \\
\hline $\begin{array}{l}\text { ASAT (Aspartate aminotransferase) } \\
(\mathrm{U} / \mathrm{L})^{*}\end{array}$ & 35 (cases:7/controls:28) & $20.0(14.0 / 28.0)$ & $17.5(13.0 / 38.0)$ & \\
\hline 1st quartile & & & & $0.63(0.08-5.26)$ \\
\hline 2nd quartile & & & & $0.37(0.04-4.01)$ \\
\hline 3rd quartile & & & & $0.34(0.03-4.41)$ \\
\hline 4th quartile & & & & Ref \\
\hline Alkaline phosphatase (ALP)* (U/L) & 385 (cases:77/controls:308) & $48.0(28.2 / 90.0)$ & $44.4(28.2 / 72.0)$ & \\
\hline
\end{tabular}


Table 3 (continued)

\begin{tabular}{|c|c|c|c|c|}
\hline & $\begin{array}{l}\mathrm{N} \text { measurements ( } \mathrm{n} \text { cases } / \mathrm{n} \\
\text { controls) }\end{array}$ & $\begin{array}{l}\text { Cases: Celiac disease } \\
\text { antibody positive } \\
\text { participants }^{\mathrm{a}}\end{array}$ & Controls & OR $(95 \% \mathrm{Cl})^{\mathrm{b}}$ \\
\hline 1st quartile & & & & $0.69(0.34-1.40)$ \\
\hline 2nd quartile & & & & $0.63(0.32-1.25)$ \\
\hline 3rd quartile & & & & $0.60(0.30-1.20)$ \\
\hline \multirow[t]{2}{*}{ 4th quartile } & & & & Ref \\
\hline & & $\%(n /$ total $N)$ & $\%(n /$ total $N)$ & \\
\hline \multirow{2}{*}{$\begin{array}{l}\text { Elevated liver parameters (ASAT/ALAT/ } \\
\text { ALP) })^{d}\end{array}$} & & $1.0(1 / 102)$ & $2.2(9 / 407)$ & $0.42(0.05-3.48)$ \\
\hline & & Median (5\%/95\%) & Median (5\%/95\%) & \\
\hline Vitamin D (nmol/L)* & 474 (cases:95/controls:379) & $50.0(10.0 / 107.0)$ & $54.0(13.0 / 102.0)$ & \\
\hline 1st quartile & & & & $1.21(0.63-2.30)$ \\
\hline 2nd quartile & & & & $1.41(0.76-2.65)$ \\
\hline 3rd quartile & & & & $1.05(0.55-2.01)$ \\
\hline 4th quartile & & & & Ref \\
\hline Vitamin B12 (pmol/L)* & 385 (cases:77/controls:308) & $286.3(159.4 / 513.6)$ & $295.9(170.5 / 492.2)$ & \\
\hline 1st quartile & & & & $1.22(0.63-2.38)$ \\
\hline 2nd quartile & & & & $0.81(0.39-1.69)$ \\
\hline 3rd quartile & & & & $0.64(0.30-1.36)$ \\
\hline 4th quartile & & & & Ref \\
\hline
\end{tabular}

*The quartiles were calculated per each of the eight studies

Statistically significant values are shown in bold

a The participants were screened for celiac disease antibodies by EliA ${ }^{\mathrm{TM}}$ Celikey ${ }^{\circledR}$ tissue transglutaminase (TTG) anti-lgA and anti-lgG assays and deamidated gliadin peptide (DGP) anti-lgG assays. Celiac disease antibody positive were defined as lgG-DGP $\geq 10.0 \mathrm{U} / \mathrm{mL}$ and/or IgA-TTG/lgG-TTG $\geq 7.0 \mathrm{U} / \mathrm{mL}$. 5 of the 16,776 participants had a diagnosis of celiac disease in the national patient register, they were all celiac disease antibody negative and were excluded before matching. Cases were matched without replacement on age (5 years range), sex and study to 4 controls

b Conditional logistic regression for comparison of cases with controls giving odds ratios (ORs) with 95\% confidence intervals (Cls)

c Low hemoglobin was defined as hemoglobin under $7.3 \mathrm{mmol} / \mathrm{L}$ for women and under $8.3 \mathrm{mmol} / \mathrm{L}$ for men

d Elevated liver parameters was defined as ALAT over $70 \mathrm{U} / \mathrm{L}$ for men and over $45 \mathrm{U} / \mathrm{L}$ for women, ASAT over $45 \mathrm{U} / \mathrm{L}$ for men and over $35 \mathrm{U} / \mathrm{L}$ for women, and alkaline phosphatase (ALP) over $105 \mathrm{U} / \mathrm{L}, 376$ participants both had measurements for ALAT and ALP

the number of cases therefore limited. It is also a limitation that we do not know the participants gluten intake, and there is a risk of misclassification of false negative if possible CD cases ate gluten-free-diet and consequently had a negative antibody screen-test. However, as these studies were conducted from 1976 to 2012 they were prior to the gluten-avoiding-trend recently described [35]. We also lack information on vitamin supplements, which could have affected the association of serum 25-hydroxy vitamin D and serum vitamin B12. The information on symptoms are collected from questionnaires, and there is a risk of recall bias and misclassification due to for example misunderstandings. Moreover, the differences in questionnaires and test for biomarkers, might be a limitation of the study, but as the cases were matched to the controls on study this limitation is limited. It is also likely that changes have occurred over time with regard to diagnostic criteria and development of improved antibody tests, which could influence our results. However, it is a strength of the study that serum samples from all eight cohorts were screened for $\mathrm{CD}$ antibodies with the same test: EliA $^{\mathrm{TM}}$ Celikey $^{\circledR}$ TTG anti-IgA and anti-IgG assay, and DGP anti-IgG assays. Another possible limitation is the potential degradation of immunoglobulins over time in frozen samples. An earlier study from our group investigated and confirmed the stability of $\operatorname{IgE}$ antibodies during eight years of storage in our biobank [36], but we do not have data on longer storage nor for other types of immunoglobulins.

\section{Conclusion}

In this population-based study comprising 16,771 individuals $1 \%$ had undiagnosed celiac seropositivity, defined by $C D$ antibody positivity with no known diagnosis of $\mathrm{CD}$. Individuals with undiagnosed celiac seropositivity were compared with $\mathrm{CD}$ antibody negative matched controls, and we found no significant differences in general or abdominal symptoms, confirming the diagnostic difficulties of $C D$ and the low prognostic value of symptoms for a diagnosis of $C D$. However, decreased levels of serum cholesterol as well as low 


\section{blood hemoglobin was associated with undiagnosed celiac seropositivity.}

\section{Supplementary Information}

The online version contains supplementary material available at https://doi. org/10.1186/s12876-021-01667-y.

Additional file 1. Additional Material (Description of the populationbased studies included), Additional Table 1 (Numbers of answers on symptoms for each symptom in the different cohorts), Additional Table 2 (Numbers and presence of biomarkers for each biomarker in the different cohorts) and Additional Table 3 (Questions from the questionnaires from the different cohorts translated to English).

\section{Abbreviations}

CD: Celiac disease; Ig: Immunoglobulin; TTG: Tissue transglutaminase; DGP: Deamidated gliadin peptide; ICD: International classification of disease; Cl: Confidence interval; BMI: Body mass index; OR: Odds ratio.

\section{Acknowledgements}

We thank all staff members at Center for Clinical Research and Prevention for contributing to the data collection and health examinations. We also thank the staff at Thermo Fisher Scientific, Allerød, Denmark, for performing the biochemical analyses of CD antibodies (Lone Søgaard, Bjarne Kristensen, and Pia Schytte Hansen).

\section{Authors' contributions}

AL was PI of the study. LLK, AL, JJR, KBL-M, LTM, JP, ALM, PS and BHT planned the study. LLK performed the statistical analyses and wrote the manuscript. AL supervised the writing process, critically revised the manuscript and contributed to the interpretation of data. KBL-M, LTM and JP contributed to the analyses and interpretation of data. ALM performed data management. All authors read and approved the final manuscript.

\section{Funding}

The study was supported by the Tryg Foundation (7-11-0213), Danish Celiac Society, The Novo Nordisk Foundation (NNF160C0022464), Independent Research Fund Denmark (7016-00122B). Thermo Fisher Scientific, Allerød, Denmark, performed the measurements of CD antibodies. Line Lund Kårhus has received a research grant from the Lundbeck Foundation (R322-2019-2530).

\section{Availability of data and materials}

The data that support the findings of this study are available from Center for Clinical Research and Prevention and from national health registers but restrictions apply to the availability of these data, which were used under license for the current study, and so are not publicly available. Data are however available from the authors upon reasonable request and with permission from appropriate Danish authorities, as access to the data are subject to Danish regulations on personal data protection.

\section{Ethics approval and consent to participate}

All studies were approved by the local Ethics Committee (the regional Ethics committee for The Capital Region of Denmark) and the participants gave their informed consent. The screening for CD in Health2006 5-year follow-up was approved on September 6, 2011 (H-3-2011-081) and measurements of CD antibodies in stored blood samples were approved on January 12, 2016 ( $H$-15014502). The study was performed in accordance with the Declaration of Helsinki.

\section{Consent for publication}

Not applicable.

\section{Competing interests}

The authors declare that they have no competing interests.

\section{Author details}

${ }^{1}$ Center for Clinical Research and Prevention, Bispebjerg and Frederiksberg Hospital, Hovedvejen, Entrance 5, Nordre Fasanvej 57, 2000 Frederiksberg, Copenhagen, Denmark. ${ }^{2}$ Section of Biostatistics, Department of Public Health, University of Copenhagen, Copenhagen, Denmark. ${ }^{3}$ The Copenhagen City Heart Study, Bispebjerg and Frederiksberg Hospital, Copenhagen, Denmark. ${ }^{4}$ Department of Endocrinology and Diabetes and Bone-Metabolic Research Unit, Rigshospitalet, Copenhagen, Denmark. ${ }^{5}$ Department of Clinical Medicine, Faculty of Health and Medical Sciences, University of Copenhagen, Copenhagen, Denmark. ${ }^{6}$ Q\&D-Research Unit and Department of Gastroenterology, Herlev and Gentofte Hospital, University of Copenhagen, Copenhagen, Denmark.

Received: 14 November 2020 Accepted: 15 February 2021

Published online: 27 February 2021

\section{References}

1. Lebwohl B, Sanders DS, Green PHR. Coeliac disease. Lancet. 2018;391:70-81.

2. Ludvigsson JF, Bai JC, Biagi F, Card TR, Ciacci C, Ciclitira PJ, et al. Diagnosis and management of adult coeliac disease: guidelines from the British Society of Gastroenterology. Gut. 2014;63:1210-28.

3. Catassi C, Kryszak D, Bhatti B, Sturgeon C, Helzlsouer K, Clipp SL, et al. Natural history of celiac disease autoimmunity in a USA cohort followed since 1974, Annals of Medicine, 42:7, 530-538. Ann Med. 2010;42:530-8.

4. Lebwohl B, Ludvigsson JF, Green PH. Celiac disease and non-celiac gluten sensitivity. BMJ. 2015;351:h4347

5. Lohi S, Mustalahti K, Kaukinen K, Laurila K, Collin P, Rissanen H, et al. Increasing prevalence of coeliac disease over time. Aliment Pharmacol Ther. 2007;26:1217-25.

6. Hujoel IA, Van Dyke CT, Brantner T, Larson J, King KS, Sharma A, et al. Natural history and clinical detection of undiagnosed coeliac disease in a North American community. Aliment Pharmacol Ther. 2018;47:1358-66.

7. Maki M, Mustalahti K, Kokkonen J, Kulmala P, Haapalahti M, Karttunen T, et al. Prevalence of Celiac disease among children in Finland. N Engl J Med. 2003;348:2517-24.

8. Rubio-Tapia A, Ludvigsson JF, Brantner TL, Murray JA, Everhart JE. The prevalence of celiac disease in the United States. Am J Gastroenterol. 2012;107:1538-44.

9. Jabri B, Sollid LM. T cells in celiac disease. J Immunol. 2017;198:3005-14.

10. Norstrom F, Lindholm L, Sandstrom O, Nordyke K, Ivarsson A. Delay to celiac disease diagnosis and its implications for health-related quality of life. BMC Gastroenterol. 2011;11:118.

11. Kurppa K, Paavola A, Collin P, Sievanen H, Laurila K, Huhtala H, et al. Benefits of a gluten-free diet for asymptomatic patients with serologic markers of celiac disease. Gastroenterology. 2014;147(610-7):e1.

12. Dydensborg S, Toftedal P, Biaggi M, Lillevang ST, Hansen DG, Husby S. Increasing prevalence of coeliac disease in Denmark: a linkage study combining national registries. Acta Paediatr. 2012;101:179-84.

13. Grode $L$, Bech BH, Jensen TM, Humaidan P, Agerholm IE, Plana-Ripoll O, et al. Prevalence, incidence, and autoimmune comorbidities of celiac disease: a nation-wide, population-based study in Denmark from 1977 to 2016. Eur J Gastroenterol Hepatol. 2017;30:83-91.

14. Horwitz A, Skaaby T, Kårhus LL, Schwarz P, Jorgensen T, Rumessen JJ, et al. Screening for celiac disease in Danish adults. Scand J Gastroenterol. 2015;50:824-31.

15. Kårhus LL, Thuesen BH, Rumessen JJ, Linneberg A. Symptoms and biomarkers associated with celiac disease: evaluation of a populationbased screening program in adults. Eur J Gastroenterol Hepatol. 2016:28:1298-304.

16. Katz KD, Rashtak S, Lahr BD, Melton LJ III, Krause PK, Maggi K, et al. Screening for celiac disease in a North American population: sequential serology and gastrointestinal symptoms. Am J Gastroenterol. 2011;106:1333-9.

17. Rosen A, Sandstrom O, Carlsson A, Hogberg L, Olen O, Stenlund H, et al. Usefulness of symptoms to screen for celiac disease. Pediatrics. 2014;133:211-8.

18. Kårhus LL, Skaaby T, Petersen J, Madsen AL, Thuesen BH, Schwarz P, et al. Long-term consequences of undiagnosed celiac seropositivity. Am J Gastroenterol. 2020;5:4. https://doi.org/10.14309/ajg.0000000000000737. 
19. Jorgensen T, Borch-Johnsen K, Thomsen TF, Ibsen H, Glumer C, Pisinger C. A randomized non-pharmacological intervention study for prevention of ischaemic heart disease: baseline results Inter99. Eur J Cardiovasc Prev Rehabil. 2003;10:377-86.

20. Jorgensen T, Jacobsen RK, Toft U, Aadahl M, Glumer C, Pisinger C. Effect of screening and lifestyle counselling on incidence of ischaemic heart disease in general population: Inter99 randomised trial. BMJ. 2014;348:g3617.

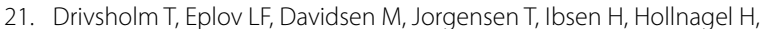
et al. Representativeness in population-based studies: a detailed description of non-response in a Danish cohort study. Scand J Public Health. 2006;34:623-31.

22. Gerdes LU, Bronnum-Hansen H, Madsen M, Borch-Johnsen K, Jorgensen T, Sjol A, et al. Trends in selected biological risk factors for cardiovascular diseases in the Danish MONICA population, 1982-1992. J Clin Epidemiol. 2000;53:427-34

23. Sjol A, Thomsen KK, Schroll M. Secular trends in blood pressure levels in Denmark 1964-1991. Int J Epidemiol. 1998;27:614-22.

24. Avlund K, Kreiner S, Schultz-Larsen K. Construct validation and the Rasch model: functional ability of healthy elderly people. Scand J Soc Med. 1993;21:233-46

25. Stovring N, Avlund K, Schultz-Larsen K, Schroll M. The cumulative effect of smoking at age 50,60 , and 70 on functional ability at age 75 . Scand J Public Health. 2004;32:296-302.

26. Linneberg A, Husemoen LL, Nielsen NH, Madsen F, Frolund L, Johansen N. Screening for allergic respiratory disease in the general population with the ADVIA Centaur Allergy Screen Assay. Allergy. 2006;61:344-8.

27. Linneberg A, Nielsen NH, Madsen F, Frolund L, Dirksen A, Jorgensen T. Smoking and the development of allergic sensitization to aeroallergens in adults: a prospective population-based study. Cph Allergy Study Allergy. 2001;56:328-32.

28. Lynge E, Sandegaard JL, Rebolj M. The Danish National Patient Register. Scand J Public Health. 2011;39:30-3.
29. Nickelsen TN. Data validity and coverage in the Danish National Health Registry. A literature review. Ugeskr Laeger. 2001;164:33-7.

30. Department of Clinical Biochemistry, Bispebjerg and Frederiksberg Hospital https://www.bispebjerghospital.dk/afdelinger-og-klinikker/klini sk-biokemisk-afdeling/for-sundhedsfaglige/analysefortegnelse/. 2019. Accessed 5 Aug 2019.

31. Choung RS, Larson SA, Khaleghi S, Rubio-Tapia A, Ovsyannikova IG, King KS, et al. Prevalence and morbidity of undiagnosed celiac disease from a community-based study. Gastroenterology. 2017;152(830-9):e5.

32. West J, Logan RF, Hill PG, Lloyd A, Lewis S, Hubbard R, et al. Seroprevalence, correlates, and characteristics of undetected coeliac disease in England. Gut. 2003;52:960-5.

33. Murray JA, McLachlan S, Adams PC, Eckfeldt JH, Garner CP, Vulpe CD, et al. Association between celiac disease and iron deficiency in Caucasians, but not non-Caucasians. Clin Gastroenterol Hepatol. 2013;11:808-14.

34. Hoerter NA, Shannahan SE, Suarez J, Lewis SK, Green PHR, Leffler DA, et al. Diagnostic yield of isolated deamidated gliadin peptide antibody elevation for celiac disease. Dig Dis Sci. 2017;62:1272-6.

35. Kim HS, Patel KG, Orosz E, Kothari N, Demyen MF, Pyrsopoulos N, et al. Time trends in the prevalence of celiac disease and Gluten-free diet in the US population: results From the National Health and Nutrition Examination Surveys 2009-2014. JAMA Intern Med. 2016;176:1716-7.

36. Linneberg A, Nielsen NH, Madsen F, Frolund L, Dirksen A, Jorgensen T. Increasing prevalence of specific IgE to aeroallergens in an adult population: two cross-sectional surveys 8 years apart: the Copenhagen Allergy Study. J Allergy Clin Immunol. 2000;106:247-52.

\section{Publisher's Note}

Springer Nature remains neutral with regard to jurisdictional claims in published maps and institutional affiliations.
Ready to submit your research? Choose BMC and benefit from:

- fast, convenient online submission

- thorough peer review by experienced researchers in your field

- rapid publication on acceptance

- support for research data, including large and complex data types

- gold Open Access which fosters wider collaboration and increased citations

- maximum visibility for your research: over 100M website views per year

At BMC, research is always in progress.

Learn more biomedcentral.com/submissions 